\title{
KARAKTERISTIK IBU YANG BERDAMPAK PADA HASIL PEMERIKSAAN IVA TES DI PUSKESMAS MUSUK KECAMATAN MUSUK BOYOLALI
}

\author{
Sri Suparti ${ }^{1}$, Ani Nur Fauziah ${ }^{2}$, Siti Maesaroh ${ }^{3}$ \\ STIKES Mamba'ul 'Ulum Surakarta \\ ( srisuparti@stikesmus.ac.id )
}

\begin{abstract}
ABSTRAK
Latar Belakang :Kanker serviks adalah kanker terbanyak pada perempuan di Indonesia dan peringkat kedua setelah kanker payudara.Penyebab utama adalah Human Papilloma Virus ( $H P V$ ).WHO merekomendasikan suatu pendekatan alternatif dengan konsep down staging terhadap kanker serviks, salah satunya dengan cara Inspeksi Visual dengan Asam Asetat (IVA).Metode pemeriksaan IVA adalah pemeriksaan yang dapat dilakukan oleh dokter/bidan/paramedis dengan cara mengamati serviks yang telah diberi asam asetat/asam cuka 3-5\% secara inspekulo / dilihat langsung dengan penglihatan mata langsung. Wanita yang melakukan pemeriksaan IVA tes di Boyolali tahun 2018 sebanyak 1.542 orang. Hasil pemeriksaan yang dinyatakan IVA tes positif 131 orang ( $8,49 \%)$. Sasaran pemeriksaan IVA tes puskesmas Musuk tahun 2018 sebanyak 17.738 orang, yang melakukan pemeriksaan 71 orang $(0,40 \%)$,hasil positif 8 orang. Penelitian ini bertujuan untuk mengetahui hubungan karakteristik ibu dengan hasil pemeriksaan IVA tes di puskesmas Musuk tahun 2019.

Metode :Penelitian ini menggunakan metode survey analitik dengan pendekatan retrospektif.Penelitian ini menggunakan subyek penelitian karena semua populasi diteliti yaitu semua ibu yang memeriksakan IVA tes sebanyak 75 orang.Alat pengumpul data berupa master table.Menggunakan data sekunder bersumber dari register pemeriksaan IVA tes dan rekam medik.

Hasil :Karakteristik responden mayoritas umur 30 - 50 tahun sebanyak 46 orag ( $61,33 \%$ ), pendidikan mayoritas tingkat dasar sebanyak 39 orang ( $52,0 \%$ ), paritas mayoritas multipara sebanyak 71 orang ( $94,66 \%)$.Hasil pemeriksaan IVA tes di puskesmas Musuk tahun 2019 mayoritas normal sebanyak 63 ( 84,0\%), hasil IVA tes positif $12(16,0 \%)$. Terdapat hubungan umur, pendidikan dan paritas dengan hasil pemeriksaan IVA tes melihat nilai Asymp.Sig.(2-sided) 0.0808, 0,00533 dan 0.051> 0,050.Terdapat hubungan antara karakteristik responden dengan hasil pemeriksaan IVA tes dibuktikan dengan uji chi square pada taraf signifikasi 0,050 didapatkan nilai Asymp. Sig. $(2$-sided $)=0,0510>$ dari signifikasi 0,050. Hubungan tingkat tinggi dengan hasil coefisien correlation sebesar 0,614 .

Simpulan:Karakteristik ibu berdampak pada hasil pemeriksaan IVA tes di puskesmas Musuk tahun 2019.
\end{abstract}

Kata kunci: Karakteristik ibu, IVA tes 


\title{
Characteristics Of Mother That Impact On Results Iva Examination Of Test At Musuk Puskesmas
}

\begin{abstract}
Background: Cervical cancer is the most cancer in women in Indonesia and ranks second after breast cancer. The main cause is Human Papilloma Virus $(H P V)$. WHO recommends an alternative approach to the concept of down staging for cervical cancer, one of which is by means of Visual Inspection with Acetic Acid (IVA). The IVA examination method is an examination that can be performed by a doctor / midwife / paramedic by observing the cervix that has been given acetic acid / 3-5\% vinegar inspulally / seen directly with direct eye vision. There were 1,542 women who took IVA tests in Boyolali in 2018. The results of tests that tested positive for IVA tested 131 people $(8.49 \%)$. The target of examining IVA in Musuk puskesmas in 2018 is 17,738 people, who have 71 people $(0.40 \%), 8$ positive results. This study aims to determine the relationship of maternal characteristics with the results of the IVA test at Musuk puskesmas in 2019
\end{abstract}

Method: This study used an analytical survey method with a retrospective approach. This study uses research subjects because all populations studied were all mothers who checked IVA tests as many as 75 people. Data collection tool in the form of a master table. Using secondary data sourced from the IVA examination register of tests and medical records of respondents.

Results: The majority of respondents aged 30-50 years were 46 people (61.33\%), he majority of primary education was 39 people (52.0\%), the majority parity of multipara was 71 people (94.66\%). The results of the IVA test in the Musuk puskesmas in 2019 were normal majority of 63 (84.0\%), with positive IVA tests 12 (16.0\%). There is a relationship of age, education and parity with the results of the IVA test seeing the Asymp.Sig. (2-sided) value of 0.0808, 0.00533 and 0.051> 0.050 . There is a relationship between the characteristics of the respondents with the results of the IVA test proven by the chi square test at the 0.050 significance level obtained Asymp value. Sig. (2-sided) $=0.0510>$ of the significance of 0.050. High-level relationship with the results of the correlation coefficient of 0.614.

Conclusions: The characteristics of the mother have an impact on the results of the IVA test at the Musuk puskesmas in 2019.

Keywords: Mother's characteristics, IVA test

\section{PENDAHULUAN}

Kanker serviks adalah kanker terbanyak pada perempuan di Indonesia dan peringkat kedua setelah kanker payudara pada perempuan (Cahyaningrum $\mathrm{F}$, 2017). Penyebab utama kanker serviks adalah Human Papilloma Virus ( HPV ). HPV type 16,18,31,45 dan 52 secara bersamaan menjadi penyebab kanker servik. Faktor resiko kanker serviks adalah merokok, immunosupresan, infeksi klamidia, diet yang tidak seimbang, obesitas, kontrasepsi oral, penggunaan IUD, kehamilan multiple, kemiskinan, penggunaan obat hormonal diethylstilbestrol. Factor lain 
yang berhubungan dengan kanker serviks adalah umur,aktifitas seksual yang terlalu muda kurang dari 16 tahun, tingkat pendidikan, paritas, multi pasangan, perokok serta riwayat condiloma ( POGI Jateng, 2012 ).WHO memberikan rekomendasi suatu pendekatan alternatif bagi negara yang sedang berkembang dengan konsep down staging terhadap kanker serviks, salah satunya dengan cara Inspeksi Visual dengan Asam Asetat (IVA).Pengolesan asam asetat 3-5\% pada serviks pada epitel abnormal akan memberikan gambaran bercak putih yang disebut acetowhite (Setiawati M, 2016 ).

Hasil penelitian Arista ( 2012 ) di puskesmas Sukadana kabupaten Buleleng Bali tahun 2012 ditemukan perbedaan statistik yang bermakna antara wanita yang menikah dibawah 21 tahun cenderung untuk terkena kanker serviks dibandingkan wanita yang menikah usia diatas 20 tahun.Dari hasil uji chi square didapatkan nilai PR 2,11 (CI 95\% $=1,274-4.935, \mathrm{p}=0,034)$ artinya terdapat hubungan yang signifikan antara usia perkawinan $<21$ tahun dengan kejadian lesi prakanker serviks dan usia perkawinan $<21$ tahun memiliki rasio prevalensi sebesar 2,11 kali lebih besar dari pada usia perkawinan > 20 tahun untuk mengalami lesi prakanker serviks. Terdapat risiko 5,85 kali pada wanita yang melakukan hubungan seksualitas umur kurang dari 20 tahun dengan kejadian kanker serviks ( Arista,AGR, 2012 ).Tingkat pendidikan merupakan faktor resiko terjadinya lesi pra-kanker serviks. Penelitian yang di lakukan Damayanti (2013) di RSUD Arifin Achmad Riau menyatakan bahwa seseorang dengan tingkat pendidikan rendah berisiko terkena kanker serviks. Penelitian oleh Ningsih et al (2017) di RSUP Sardjito Yogyakarta menyatakan bahwa tingkat pendidikan tinggi (SMA, D3/S1/S2) lebih banyak terkena kanker serviks dari pada tingkat pendidikan rendah (tidak sekolah-SMP). Paritas $>3$ dan tingkat pendidikan rendah merupakan faktor risiko yang dapat meningkatkan terjadinya kanker serviks dengan $\mathrm{p}=0,000$ untuk paritas, dan $\mathrm{p}=0,000$ untuk tingkat pendidikan ( Asyifa F, 2018). Penelitian yang dilakukan Khasbiyah, mempunyai paritas lebih dari dua meningkatkan risiko terjadinya kanker serviks sebanyak 8,11 dengan $\mathrm{p}=$ 0,000018 kali dibandingkan yang mempunyai anak dibawah tiga ( Khasbiyah, 2004)

Untuk mengurangi morbiditas dan mortalitas kanker serviks perlu upayaupaya pencegahan, yang terdiri dari beberapa tahap. Pencegahan Primer yang dilakukan pada tahap ini adalah promosi, edukasi serta vaksinasi HPV (Human Papilloma Virus). Pencegahan sekunder yaitu melakukan deteksi dini. Melalui pemeriksaa IVA tes dilanjutkan pengobatan untuk kasus yang ditemukan pada deteksi dini serta mencegah komplikasi dan kematian awal ( Cahyaningrum, 2017)

Hasil studi pendahuluan yang dilakukan peneliti di puskesmas Musuk pada bulan September 2019 terdapat 17 orang yang melakukan pemeriksaan IVA tes, hasilnya dinyatakan positif sebanyak 2 orang (11,76\%). Wanita yang dinyatakan IVA tes positif dilakukan pengobatan kryo-therapi oleh dokter puskesmas yang terlatih IVA tes. ( Puskesmas Musuk, 2019)

Berdasarkan uraian di atas, maka peneliti tertarik untuk mengetahui " Karakteristik Ibu Yang Berdampak Pada Hasil Pemeriksaan IVA Tes di Puskesmas Musuk Boyolali tahun 2018". 


\section{METODE PENELITIAN}

Penelitian ini merupakan penelitian surveyanalitik dengan pendekatan retrospektif. Subyek penelitian ini semua ibu yang memeriksakan IVA tes di puskesmas Musuk Boyolali berjumlah 75 orang.

Penelitian ini menggunakan alat pengumpul data berupa master table, Metode pengumpulan data yangdigunakan adalah pengumpulan data sekunder. Pengumpulan data sekunderhasil pemeriksaan IVA tes dilakukan dengan cara melihat dokumen atau catatan yang mendukung data penelitian melalui buku register pemeriksaan IVA tes di puskemas. Selanjutnya menelusuri data karakteristik responden dengan melihat dokumen pemeriksaan IVAtes berupa catatan rekam medic yang tergabung dalam kartu keluarga atau familyfolder.Analisa data univariate dengan persentase, untuk analisa data bivariate hubungan karakteristik responden dengan hasil pemeriksaan IVA menggunakan analisa korelasi chi-square.

\section{HASIL DAN PEMBAHASAN}

\section{Hasil}

Tabel 1 Distribusi Frekwensi Karakteristik Responden Berdasarkan Umur, Pendidikan, dan Paritas

\begin{tabular}{llcc}
\hline NO & Kelompok Umur & Frekuensi & Persentase \\
\hline 1 & $<30$ tahun & 18 & 24,00 \\
2 & $30-50$ tahun & 46 & 61,33 \\
3 & $>50$ tahun & 11 & 14,67 \\
& Total & 75 & 100,0 \\
& & & \\
NO & Pendidikan & Frekuensi & Persentase \\
1 & Dasar & 39 & 52,00 \\
2 & Menengah & 29 & 36,66 \\
3 & Tinggi & 7 & 9,34 \\
& Total & 75 & 100,0 \\
No & Paritas & Frekuensi & Persentase \\
1. & Primpara & 4 & 5,34 \\
2. & Multipara & 71 & 94,66 \\
& Total & 75 & 100,0 \\
\hline
\end{tabular}

Berdasarkan Tabel 1. dapat dilihat bahwa menurut karakteristik umur responden mayoritas adalah umur30-50 tahun yaitu 46 orang $(61,33 \%)$, menurut karakteristik pendidikan mayoritas adalah tingkat pendidikandasar yaitu 39 orang $(52,00 \%)$,menurut karakteristik paritas mayoritas adalah multipara ada 71 orang $(94,66 \%)$. 
Tabel 2. Distribusi frekuensi variabel hasil pemeriksaan IVA di Puskesmas Musuk Boyolali tahun 2019.

\begin{tabular}{|c|c|c|c|}
\hline No & Hasil IVA tes & Frekuensi & Persentase \\
\hline 1. & Normal/ negatif & 63 & 84,00 \\
\hline \multirow[t]{2}{*}{2.} & Positif & 12 & 16,00 \\
\hline & Total & 75 & 100,0 \\
\hline
\end{tabular}

Berdasarakan tabel 2 diatas menunjukkan bahwa hasil pemeriksaan IVA tes mayoritas normal sebanyak $63(84,00 \%)$

Tabel 3:Tabel silang karakteristik responden dengan hasil IVA tes di puskesmas Musuk tahun 2019.

\section{Hasil IVA tes}

\begin{tabular}{|c|c|c|c|c|c|c|c|}
\hline \multirow{2}{*}{ No } & \multirow{2}{*}{$\begin{array}{c}\text { Karakteristik } \\
\text { responden }\end{array}$} & \multirow[b]{2}{*}{$\begin{array}{c}\text { Freku } \\
\text { ensi }\end{array}$} & \multirow[b]{2}{*}{$\begin{array}{l}\text { Persen } \\
\text { tase }\end{array}$} & \multicolumn{2}{|c|}{ Normal/negatif } & \multicolumn{2}{|c|}{ Positif } \\
\hline & & & & $\begin{array}{c}\text { Freku } \\
\text { ensi }\end{array}$ & $\begin{array}{c}\text { Persen } \\
\text { tase }\end{array}$ & $\begin{array}{c}\text { Freku } \\
\text { ensi }\end{array}$ & $\begin{array}{c}\text { Persen } \\
\text { tase }\end{array}$ \\
\hline \multirow[t]{5}{*}{1.} & Umur : & & & & & & \\
\hline & $<30$ th & 18 & 24,0 & 16 & 21,33 & 2 & 2,67 \\
\hline & $30-50$ th & 46 & 61,33 & 38 & 50.66 & 8 & 10,66 \\
\hline & $>50$ th & 11 & 14,67 & 9 & 1,01 & 2 & 2,67 \\
\hline & Total & 75 & 100,0 & 63 & 84,00 & 12 & 16,00 \\
\hline \multirow[t]{5}{*}{2.} & Pendidikan: & & & & & & \\
\hline & Dasar & 39 & 52,00 & 34 & 45,33 & 5 & 6,66 \\
\hline & Mengah & 29 & 38,66 & 24 & 32,00 & 5 & 6,66 \\
\hline & Tinggi & 7 & 9,34 & 5 & 6,67 & 2 & 2,28 \\
\hline & Total & 75 & 100,0 & 63 & 84,00 & 12 & 16,00 \\
\hline \multirow[t]{4}{*}{3.} & Paritas: & & & & & & \\
\hline & Primipara & 4 & 5,34 & 3 & 4,01 & 1 & 1,33 \\
\hline & Multipara & 71 & 94,66 & 60 & 79,99 & 11 & 14,67 \\
\hline & Total & 75 & 1000 & 63 & 100,0 & 12 & 16,00 \\
\hline
\end{tabular}

Berdasarkan table 3 Menunjukkkan Karakteristik umur mayoritas umur 30-50 tahun sebanyak 46 ( 61,33\%), mayoritas hasil IVA tes negatif sebanyak $38(50,66 \%)$.Karakteristik pendidikan mayoritas pendidikan dasar sebanyak 39 ( $52,00 \%)$, mayoritas hasil IVA tes negatif sebanyak 34 (45,33\%).Karakteritik paritas mayoritas multipara sebanyak 71 (94,66\%), hasil IVA tes mayoritas negatif sebanyak $60(79,99 \%)$ 
Tabel 4. Hubungan umur, tingkat pendidikan dan paritas dengan hasil IVA tes di puskesmas Musuk tahun 2019.

\begin{tabular}{lrr}
\hline & Value & Approx. Sig \\
\hline Ordinal by nominal & & \\
Contingensi Coefficient & 0,075 & \\
Nof Valid Cases & 75 & \\
Ordinal by nominal & & \\
Contingensi Coefficient & 0,0129 & \\
Nof Valid Cases & 75 & \\
Ordinal by nominal & & \\
Contingensi Coefficient & 0,058 & 0,0510 \\
Nof Valid Cases & 75 & \\
\hline
\end{tabular}

Berdasarkan tabel 4 Menunjukkananalisis bivariate dengan menggunakan analisis Chi-Square menunjukan nilai $r$ hitung atau nilai Exct.Sig ( 2-sided) karakteristik umur, tingkat pendidikan dan paritas masing-masing sebesar 0,0808, 0,053 dan 0,0510>0,050, sehingga umur, tingkat pendidikan dan paritas terdapat hubungan dengan hasil pemeriksaan IVA tes di puskesmas Musuk tahun 2019 ( Sugiono,2014 )

Tabel 5 Analisa Bivariat Chi Square Hubungan Karakteristik Responden. DenganHasil Pemeriksaan IVA tes di Puskesmas Musuk tahun 2019

\begin{tabular}{|c|c|c|c|c|c|}
\hline & Value & df & $\begin{array}{c}\text { Asymp.Sig. } \\
\text { (2-sided) }\end{array}$ & $\begin{array}{l}\text { Exact sig. } \\
(2 \text {-sided })\end{array}$ & $\begin{array}{c}\text { Exact sig } \\
1 \text {-sided) }\end{array}$ \\
\hline Pearson Chi-Square & $.255^{\mathrm{a}}$ & 1 & .614 & & \\
\hline Continuity Correction $^{b}$ & .000 & 1 & 1.000 & & \\
\hline Likelihood Ratio & .226 & 1 & .634 & & \\
\hline Fisher's Exact Tes & & & & .0510 & .0510 \\
\hline Linear-by-linear Assosation & .251 & 1 & .616 & & \\
\hline$N$ of Valid Cases & 75 & & & & \\
\hline
\end{tabular}

a. 2 cells ( 50,0\%) have expected count less than 5. The minium ecpected count is .64

b. Computed only for a $2 \times 2$ table

Berdasarkan tabel 5 diketahui hasil koefisien korelasi dengan uji statistik Chi Square didapatkan hasilAsymp.Sig ( 2-sided )sebesar 0,0510 dengan angka signifikan 0,050. Sehingga hasil Asymp.Sig ( 2-sided) 0,0510>dari 0,05 (>dari signifikasi 0,050. Maka $\mathrm{H}_{\mathrm{a}}$ diterima, $\mathrm{H}_{\mathrm{o}}$ ditolak, artinya terdapat hubungan karakteristik responden dengan hasil pemeriksaan IVA tes di puskesmas Musuk tahun 2019. Hubungan 2 variabel atau coeffisien corelation sebesar 0,614 sehingga terdapat hubungan tingkat tinggi( Sugiono, 2014 ). 


\section{Pembahasan}

Berdasarkan tabel 1 menunjukkan responden yang melakukan pemeriksaan IVA tes mayoritas umur 30 - 50 tahun sebanyak 46 responden $(61,33 \%)$. Hasil ini sesuai dengan target sasaran pemeriksaan IVA tes kelompokumur 30 - 50 tahun dari tingkat nasional sampai tingkat puskesmas ( Profil Kesehhatan Boyolali, 2018 ). Cakupan pemeriksaan IVA tes di Jawa Tengah tahun 2018 sebesar 5,075\% dari target sasaran pada wanita usia 30-50 tahun. Cakupan yang kurang disebabkan oleh beberapa factor antara lain perasaan takut, malu, merasa sehat sehingga tidak perlu periksa serta tanda gejala yang dirasakan oleh wanita ( Profil Kesehatan Jawatengah, 2018 ). Responden yang melakukan pemeriksaan IVA tes berdasarkan karakteristik pendidikan mayoritas pendidikan dasar sebanyak 39 responden ( 52,0\% ). Hal ini sesuai dengan tingkat pendidikan penduduk perempuan di wilayah puskesmas Musuk mayoritas pendidikan dasar ( Profil Din-Kes Boyolali, 2018 ).Karakteristik responden yang melakukan pemeriksaan IVA tes berdasar paritas mayoritas multipara sebanyak 71 responden ( 94,66\% ). Hasil ini sesuai dengan penelitian Hakimah U,2015 yang menyatakan tingkat kesadaran perempuan muda khususnya primipara akan bahaya kanker serviks serta untuk melakukan deteksi dini kanker serviks masih rendah, ada wanita yang mereka merasa malu dan takut akan hasil pemeriksaan IVA tes sehingga mereka kehilangan semangat hidup jika mengetahui bahwa dirinya menderita kanker jika diketahui hasil pemeriksaan menunjukkan adanya lesi kanker ( Hakimah U, 2015 )

Berdasarkan tabel 2 hasil penelitian menunjukkan hasil pemeriksaan IVA tes di puskesmas Musuk dari 75 responden mayoritas normal atau negatif sebanyak 63 responden ( 84,00\%), 12 responden ( 16,00\%) hasil IVA tes positif. Hasil ini temasuk tinggi dari 10 orang yang periksa 1-2 orang dinyatakan IVA tes positif. Cakupan kasus pemeriksaan IVA tes meningkat dibanding tahun 2018 sebanyak 71 orang $(0,40 \%)$ dari target sasaran pemeriksaan IVA tes sebanyak 17.738 orang). Sedang kasus IVA tes positif juga meningkat semula 8 orang ( $11,26 \%)$ dari 71 orang yang diperiksa tahun 2018, menjadi 12 orang ( $16,00 \%$ ) dari 75 orang yang diperiksa tahun 2019 ( Profil Kesehatan Kabupaten Boyolali, 2018 ). Hal ini menunjukkan bahwa upaya yang dilakukan oleh Dinas Kesehatan Boyolali beserta jajarannya khususnya puskesmas Musuk berupa penyuluhan kelompok, konseling individu, pemberian vaksinasi HPV, serta pemeriksan IVA tes secara massal belum menunjukkan hasil yang menggembirakan karena terjadi kenaikan persentase dari kasus IVA tes positif (Profil Kesehatan Kabupaten Boyolali, 2018 )

Berdasarkan tabel 3 hasil penelitian menunjukkan responden dominan umur $30-50$ tahun sebanyak 46 ibu (61,33\%). Dengan rincian 38 responden hasil IVA tes normal atau negatif $(50,66 \%)$ dan 8 orang responden ( $13,04 \%)$ hasil pemeriksaan IVA tes positif. Umur kurang 30 tahun 18 responden $(24,00 \%), 16$ responden $(21,33 \%)$ hasil IVA tes normal atau negatif, 2 responden ( $2,67 \%$ ) hasil IVA tes positif. Umur lebih 50 tahun 11 responden (14,67\%), 9 orang responden $(12,01 \%)$ hasil IVA tes normal atau negatif, sebanyak 2 reponden $(2,67 \%)$ hasil IVA tes positif. Hasil mayoritas kelompok umur $30-50$ tahun sesuai dengan target sasaran pemeriksaan IVA tes di kabupaten Boyolali 
tahun 2018 menetapkan sasaran pemeriksaan IVA tes pada wanita usia $30-50$ tahun sebanyak 153.062 orang (Profil Kesehatan Boyolali, 2018). Hasil pemeriksaan IVA tes positif mayoritas kelompok umur 30-50 tahun sebanyak 8 responden ( 10,66\% ). Penderita kanker servik mayoritas berumur antara $30-$ 60 tahun, terbanyak antara 45 - 50 tahun, frekwensinya masih meningkat sampai kira - kira golongan umur 60 tahun dan selanjutnya frekwensi ini sedikit menurun kembali. Hal tersebut menjadikan alasan WUS menjadi sasaran deteksi dini kanker serviks (Andrijono, 2009 ).

Responden yang melakukan pemeriksaan IVA tes mayoritas pendidikan dasar ( SD dan SMP) sebanyak 39 orang ( $52.00 \%$ ) dengan rincian 34 responden $(45,33 \%)$ hasil IVA tes normal atau negatif, 5 orang $(6,66 \%)$ hasil IVA tes positif. Pendidikan menengah 29 responden (38,66\%), 24 reponden (32,00\%) hasil IVA tes normal atau negatif, 5 orang $(6,66 \%)$ hasil IVAtes positif. Pendidikan tingi sebanyak 7 responden ( 9,34\%), 5 responden ( 6,66\%) hasil IVA tes normal atau negatif, 2 responden ( $2,68 \%$ ) hasil IVA tes positif. Tingkat Pendidikan merupakan factor resiko terjadinya lesi pra-kanker serviks. Pendidikan mempunyai pengaruh yang besar terhadap tingkat motivasi seseorang, semakin baik tingkat pendidikan semakin mudah orang tersebut untuk menerima informasi. Motivasi dan tindakan seseorang yang didasari oleh pendidikan akan lebih mudah menyerap informasi sehingga masalahnya terselesaikan kemudian muncul respon positif ( Arfianti R,2010 )

Paritas responden yang melakukan pemeriksaan IVA tes mayoritas multipara sebanyak 71 responden (94,6\% ), 60 responden $(79,99 \%)$ hasil IVA tes normal atau negatif, 11 respondn $(14,67 \%)$ hasil IVA tes positif, Paritas primipara sebanyak 4 responden $(5,34 \%), 3$ responden $(4,01 \%)$ hasil IVA tes normal atau negatif, 1 responden $(1,33 \%)$ hasil IVA tes positif. Multiparitas terutama dihubungkan dengan kemungkinan menikah pada usia muda, disamping itu dihubungkan pula dengan sosial ekonomi yang rendah dan higiene yang buruk. Kehamilan dan persalinan yang melebihi 2 orang dan jarak kehamilan terlalu dekat akan meningkatkan kejadian kanker serviks ( Asyifa F,2018 )

Berdasarkan table 4 hasil uji chi-square karakteristik umur menunjukkan hasil Asymp. Sig. ( 2-sided ) 0.0808 lebih besar dari nilai $r$ tabel 0,050. Artinya ada hubungan antara umur responden terhadap pemeriksaa IVA tes ( Sugiyono, 2014). Umur saat berhubungan seksual pertama kurang 15 tahun beresiko menderita kanker serviks, lama menikah meningkatkan resiko terkena kanker serviks 5 kali lebih besar (Andrijono,2009 ). Hasil ini sesuai denga hasil penelitian Cahyaningrum yang menyebutkan kanker serviks jarang terjadi pada wanita muda (usia 20 tahunan). Kanker ini cenderung terjadi pada wanita paro baya, sebesar 50\% kasus ditemukan pada wanita usia 35-55 tahun; 50\% lagi ditemukan pada wanita dibawah usia 35 tahun ( Cahyaningrm, 2017).

Hasil uji chi-square hubungan pendidikan dengan hasil IVA tes pada tabel 4 menunjukkan hasil Asymp. Sig. (2-sided) 0.0533 lebih besar dari nilai $r$ tabel 0,050. Ada hubungan antara pendidikan responden terhadap hasil pemeriksaan IVA tes ( Sugiyono, 2014 ). Hasil ini didukung oleh penelitian Ningsih et al (2017) di RSUP Sardjito Yogyakarta menyatakan bahwa tingkat pendidikan tinggi (SMA, D3/S1/S2) lebih banyak terkena kanker serviks dari 
pada tingkat pendidikan rendah (tidak sekolah-SMP). Paritas > 3 dan tingkat pendidikan rendah merupakan faktor risiko yang dapat meningkatkan terjadinya kanker serviks dengan $p=0,000$ untuk paritas, dan $\mathrm{p}=0,000$ untuk tingkat pendidikan ( Asyifa F, 2018). Pendidikan merupakan faktor tejadinya kanker servik hal ini ditunjukkan penelitian yang di lakukan Damayanti (2013) di RSUD Arifin Achmad Riau menyatakan bahwa seseorang dengan tingkat pendidikan rendah berisiko menderita kanks serviks, karena sulit menerima informasi.Hasil penelitian ini juga didukung hasil penelitian Asyifa F, 2018 analisis bivariat tingkat pendidikan didapatkan $\mathrm{P}=0,029$ yang artinya terdapat hubungan antara tingkat pendidikan dengan kejadian kanker serviks karena (p) > 0,05 uji ChiSquare (x2). Hal ini terjadi karena semakin tinggi tingkat pendidikan seseorang, semakin mudah seseorang tersebut dalam memperoleh informasi tentang kanker serviks sehingga semakin banyak pengetahuan yang dimilikinya. Seseorang yang memiliki tingkat pendidikan yang tinggi cenderung mempunyai pola pikir yang lebih berkembang. Pada penelitian ini didapatkan tingkat pendidikan berhubungan dengan kanker serviks, tingkat pendidikan rendah mempengaruhi pengetahuan tentang kanker serviks. Tingkat pengetahuan pasien yang rendah tentang kanker serviks sehingga mengakibatkan responden kurang memperhatikan kebersihan genital dan terlambat melakukan deteksi dini kanker serviks. Penelitian ini sesuai dengan penelitian yang dilakukan oleh Damayanti (2013) dengan hasil $P=0,000$ yang menyatakan bahwa tingkat pendidikan dengan kejadian kanker serviks terdapat hubungan yang kuat, dimana kanker serviks cenderung lebih banyak terjadi pada wanita yang berpendidikan rendah dibanding wanita berpendidikan tinggi. Tinggi rendahnya pendidikan berkaitan dengan tinggi rendahnya sosiol ekonomi, kehidupan seksual dan kebersihan ( Rahayu DS, 2014 ).

Hasil uji chi-square hubungan paritas dengan hasil pemeriksaan IVA tes menunjukkan hasil A symp. Sig. (2-sided) 0.0510 lebih besar dari nilai $r$ tabel 0,050. Ada hubungan antara paritas responden terhadap hasil pemeriksaan IVA tes ( Sugiyono, 2014 ). Hasil ini didukung oleh penelitian yang dilakukan Khasbiyah,2004, ibu yang mempunyai paritas lebih dari dua meningkatkan risiko terjadinya kanker serviks sebanyak 8,11 dengan $\mathrm{p}=0,000018$ kali dibandingkan yang mempunyai anak dibawah dua. Tetapi tidak sejalan dengan penelitian yang dilakukan Lestari ND, 2016, di kabupaten Sukoharjo dimana tidak terdapat hubungan antara paritas dengan kasus kankers serviks dengan nilai $\mathrm{p}=0,33$.

Berdasarkan tabel 5 hubungan karakteristik dengan hasil pemeriksaan IVA tes dengan analisisa data chi-square ditemukan hasil Asymp. Sig. (2-sided) 0.0510 lebih besar dari signifikasi 0,050. Harga atau hasil nilai $r$ hitung atau nilai Asymp.sig ( 2-talied) lebih dari nilai signifikasi ( 0,05), maka terdapat hubungan antara karakteristik responden dengan hasil pemeriksaan IVA tes, artinya Ha diterima, Ho ditolak (Sugiyono,2014 ) Sehingga dapat disimpulkan terdapat hubungan antara karakteristik responden dengan hasil pemeriksaan IVA tes di puskesmas Musuk tahun 2019.

Tingkat hubungan karakteristik responden dengan hasil pemeriksaan IVA tes terdapat hubungan tinggi atau signifikan. Hal ini ditunjukkan dengan melihat hasil dari coeffisien correlation antar variabel. Hasil penelitian ini menunjukkan 
coeffisien correlation sebesar 0,641. Sehingga terdapat hubungan tingkat tinggi atau signifikan antara karakteristik responden dengan hasil pemeriksaan IVA tes di puskesmas Musuk tahun 2019. Kriteria tingkat hubungan atau coefisien correlation antar variable antara $\pm 0,000$ sampai $\pm 1,000$. Tanda + adalah positif dan tanda - adalah negative ( Sugiyono, 2014)

Umur saat melakukan hubungan seksual pertama kali, jumlah kehamilan serta pendidikan merupakan factor terjadinya kanker serviks ( Rasjidi, 2007 ). Hasil ini didukung penelitian Asyifa F, 2018 dengan analisis bivariat tingkat pendidikan didapatkan $\mathrm{P}=0,029$ yang artinya terdapat hubungan antara tingkat pendidikan dengan kejadian kanker serviks karena (p) < 0,05 uji Chi Square $(\chi 2)$. Hal ini terjadi karena semakin tinggi tingkat pendidikan seseorang, semakin mudah seseorang tersebut dalam memperoleh informasi tentang kanker serviks sehingga semakin banyak pengetahuan yang dimilikinya. Seseorang yang memiliki tingkat pendidikan yang tinggi cenderung mempunyai pola pikir yang lebih berkembang dan lebih logis. Analisis bivariat variable paritas didapatkan $\mathrm{P}=0,015$ yang artinya terdapat hubungan antara paritas dengan kejadian kanker serviks dengan nilai (p) > 0,05 uji Chi Square $(\chi 2)$. Paritas menjadi salah satu faktor awal terjadinya perubahan sel abnormal serviks karena pada saat melahirkan imunitas tubuh pada ibu mengalami penurunan dan terjadi trauma pada serviks. Keadaan ini apabila terjadi secara terus menerus dengan jangka waktu yang pendek maka dapat menyebabkan serviks lebih rentan terhadap virus HPV. Berdasarkan teori semakin tinggi paritas maka insidensi kanker serviks akan semakin tinggi, namun tingginya paritas bukan sebagai penyebab tetapi sebagai salah satu faktor risiko untuk terinfeksi HPV. Trauma pada serviks dan seringnya terjadi perlukaan di organ reproduksi saat melahirkan dapat mempermudah masuknya HPV sebagai agen penyebab terjadinya kanker serviks. Perubahan komposisi hormon progesterone dan esterogen saat kehamilan juga menyebabkan pengaruh pada HPV dan perkembangan kanker ( Asyifa F, 2018).

Hasil penelitian juga didukung oleh penelitian Damayanti,2013 yang menunjukkan wanita yang berpendidikan rendah 4 kali lebih berisiko menderita kanker serviks dibandingkan dengan wanita yang berpendidikan tinggi (OR 3,698), wanita yang usia pertama kali berhubungan seksual kurang dari 20 tahun lebih berisiko 3 kali menderita kanker serviks dibandingkan dengan wanita yang usia pertama kali berhubungan seksual diatas 20 tahun (OR 2,792), dan wanita yang memiliki paritas $>3$ anak lebih berisiko 7 kali dibandingakn dengan wanita yang memiliki paritas < anak 3 (OR 3,396).

Hasil penelitian ini tidak sesuai dengan hasil penelitian Mannopo I J,2014 yang menyebutkan tidak ada hubungan paritas dan usia ibu dengan kanker serviks dengan melihat nilai signifikan 2 tailed antara paritas dengan kanker serviks adalah $0.005(\mathrm{P}<0.05)$, Nilai signifikan 2 tailed antara usia ibu dengan kanker serviks adalah $0.007(\mathrm{P}<0.05)$. 


\section{SIMPULAN DAN SARAN}

\section{Simpulan}

Hasil penelitian menunjukkan karakteristik umur responden mayoritas 30 - 50 tahun sebanyak 46 responden ( $61,33 \%$ ). Karaktistik pendidikan mayoritas pendidikan dasar sebanyak 39 responden ( 52,0\% ). Karakteristik paritas mayoritas multipara sebanyak 71 responden ( 94,66\% ). Hasil pemeriksaan IVA tes di puskesmas Musuk tahun 2019 mayoritas normal atau negatif sebanyak 63 responden ( $84,0 \%$ ). Terdapat hubungan umur responden, pendidikan dan paritas dengan hasil pemeriksaan IVA tes ditunjukkan dengan analisa chi-square masingmasing 0,808 untuk umur, 0,0533 untuk pendidikan dan 0,0510 untuk paritas > dari $\mathrm{r}$ table 0,05 . Terdapat hubungan tinggi antara karakteristik responden dengan hasil pemeriksaan IVA tes di puskesmas Musuk tahun 2019 ditunjukkan melalui hasil analisa bivariat dengan chi-square $0,0510>$ dari $r$ table 0,05 . Serta melihat hasil coeffisien correlation sebesar 0,641.

\section{Saran}

Bagi intitusi pelayanan kesehatan dapat memanfaatkan hasil penelitian sebagai acuan dalam menyusun program kegiatan kesehatan reproduksi, melajutkan upaya meningkatkan motivasi pasangan usia subur untuk melakukan deteksi dini kanker serviks dengan IVA tes.Bagi intitusi pendidikan dapat menjadi referensi Prodi D III Kebidanan sebagai bahan masukan agar dapat menghasilkan lulusan bidan yang professional sehingga mampu memberikan asuhan kebidanan komprehensif khususnya kesehatan reproduksi.Bagi tenaga kesehatan khususnya bidan dapat meningkatkan motivasi pemeriksaan deteksi dini kanker serviks. Sehingga cakupan pemeriksaan dapat meningkat serta dapat menindaklanjuti hasil pemiksaan dengan optimal.Peneliti dan peneliti lanjutan, hasil penelitian ini dapat menjadi acuan untuk mengembangkan penelitian yang lebih luas tentang kanker serviks sehingga dapat menjawab tantangan permasalahan kesehatan reproduksi yang semakin komplek

\section{DAFTAR PUSTAKA}

Arfianti R, 2010; Faktor yang Mempengaruhi Wanita Usia Subur ( WUS ) dalam Deteksi Kanker Leher Rahim dengan Metode IVA di Wilayah Kerja Puskesmas Tlogosari Kulon Dini Kota Semarang Tahun 2010 http://uns.ac.id.http://www.google.co.id. Diakses tanggal 14 Oktober 2019 jam 17.0

Asyifa F, 2018; Hubungan Antara Paritas Dan Tingkat Pendidikan Terhadap Kejadian Kanker Serviks Di RS Dr Muwardi Surakarta Tahun 2018. http://eprints.ums.ac.id/69718/23/NASKAH\%20PUBLIKASIfaniii.pdf

Diakses 16 Oktober 2019 Jam 13.00

Arista.AGR,2012; Hubungan Paritas dan Usia Perkawinan Sebagai factor Resiko Lesi Pra Kanker Serviks pada Ibu Pasangan Usia Subur di Wilayah Kerjaa Puskesmas Sukadana IIKabupaten Buleleng Tahun 2012. https://journal.unimus.ac.id. Diakses tgl 06 Oktober 2019 jam 16.00 
Andrijono, (2009).Kanker serviks. Jakarta: Divisi Onkologi Departemen ObstetriGinekologi Fakultas Kedokteran Universitas Indonesia

Cahyaningrum F, 2017; Hubungan Usia, Paritas dan Personal Hygiene Dengan Hasil Pememeriksaan IVA Tes di Puskesmas Brangsong II Kabupaten Kendal tahun 2017 https://journal.unimus.ac.id/index.php/jur_bidDiakses tgl 09 Oktober 2019 Jam 17.00

Dinas Kesehatan Provinsi Jawa Tengah, 018; Buku Saku Kesehatan Provinsi Jawa Tengah Tahun 2018. Semaranghttps://dinkesjateng.go.idSemarang

Dinas Kesehatan Kabupaten Boyolali,2018; Buku Profil Kesehatan Kabupaten Boyolali Tahun 2018, Boyolalihttp://dinkes.boyolalikab.go.id

Damayanti, I.P., 2013. Faktor-faktor yang Berhubungan dengan Kejadian Kanker Serviks diRSUD Arifin Achmad Pekanbaru 2008-2010. Jurnal Kesehatan Komunitas. 2: 8893. http://jurnal.htp.ac.id/index.php/keskom/article/download/51/40

Hakimah U, 2015; Hubungan Usia Mnikah dan Paritas Dengan Tindakan PapSmear Di Yayasan Kanker Wisnu Wardhana Surabaya Tahun 2015 https://media.neliti.com Diakses tgl 12 Oktober 2019 Jam 20.00

Khasbiyah. (2004). Beberapa Faktor Risiko Kanker Serviks Uteri (Studi Pada Penderita Kanker Serviks Uteri Di Rumah Sakit Dokter Kariadi Semarang Pada Bulan Agustus-September2004).

Lestari ND, 2016; Faktor Yang Berhubugan Dengan Kejadian IVA Tes Positif Pada Wanita Berusia 30-50 Tahun Di Kabupaten Suoharjo Tahun 2016 https://lib.unnes.ac.id/28267/1/64114120019.pdfDiakses $21 \quad$ Oktober 2019jam 19.00

Manoppo IJ,2014; Hubungan Paritas Dan Usia Ibu Dengan Kanker Serviks Di $R S U$ Prof Kandau Kabupaten Manado Tahun 2014 https://media.nelii.com/media/publication/130645-IDDiakses $\quad$ tgl 18 Oktober 2019 Jam 20.0

Ningsih, D.P.S., Pramono, D., Siti, D.N., 2017. Faktor-faktor yang Berhubungan dengan Kejadian Kanker Serviks di RSUP Dr. Sarjidto Yogyakarta. Berita Kedokteran Masyarakat

POGI Jateng, 2012; Pelatihan IVA dan Pencegahan Kanker Serviks, Semarang, Pokja Ginekologi-Onkologi

Puskesmas Musuk, 2019; Pencatatan dan pelaporan puskesmas Musuk, Musuk, Boyolaliwww.puskesmasmusukboyolali.go.id

Rasjidi I, 2007;Vaksin Human Papilloma Visus dan Eradikasi Kanker Mulut Rahim, Jakarta, Sagung Seto

Rahayu DS,2014; Asuhan Kebidanan Kanker Serviks, Jakarta, Salemba Medika

Setiawati M, 2016: Hubungan Gejala Klinis DanFaktorResiko Dengan Hasil Pemeriksaan IV tes Pada asangan Usia Subur di Puskesmas Kedaton Bandar Lampung Tahun 2016. http://digilib.unila.ac.id/26088/3/SKRIPSI Diunduh tanggal 09 Oktober 2019 